\title{
Antibacterial and antioxidant activity of pulp, peel and leaves of Feijoa sellowiana: Effect of extraction techniques, solvents and concentration
}

\section{Barış KARSLI}

Cite this article as:

Karsl1, B. (2021). Antibacterial and antioxidant activity of pulp, peel and leaves of Feijoa sellowiana: Effect of extraction technques, solvents and concentration. Food and Health, 7(1), 21-30. https://doi.org/10.3153/FH21003

Recep Tayyip Erdogan University, Faculty of Fisheries, Department of Seafood Processing Technology, 53100 Rize, Turkey

ORCID IDs of the authors: B.K. 0000-0002-3944-6988

\section{Submitted: 14.08 .2020}

Revision requested: 11.09 .2020

Last revision received: 14.09 .2020

Accepted: 14.09 .2020

Published online: 07.11 .2020

\section{Correspondence:}

Barış KARSLI

E-mail: baris.karsli@erdogan.edu.tr

\begin{abstract}
The present study evaluated the effect of extraction techniques (ultrasound-assisted extraction (U) and shaking water bath extraction (WB)), solvents (ethanol, acetone and distilled water) and concentration $(2.5 \%$ and $5 \%)$ on total phenolic content (TPC), antibacterial and antioxidant activities of extracts obtained from feijoa leaves, peel and pulp. The antibacterial activity of feijoa extracts were tested in vitro against 6 pathogens bacteria by the disc diffusion method and the antioxidant activity was evaluated by 2,2 diphenyl-1-picrylhydrazyl radical assay. The results indicated that leaves and peel extracts exhibited stronger antibacterial activity than that of pulp. In generally, WB-A5\%, WB-W5\%, U-A5\% and U-W 5\% extracted with acetone (A) and water (W) at 5\% concentration from feijoa leaves, peel and pulp showed more antibacterial activity against all tested pathogen bacteria. The leaves, peel, and pulp extracts had high antioxidant activity with 85.78 $90.82 \%, 89.86-91.60 \%$, and $81.49-91.31 \%$, respectively. Peel extracts had slightly higher antioxidant activity than leaves and pulp extracts. TPC of leaves, peel, and pulp extracts were in the range of 488.99-554.00, 349.17-517, and 115.64-345.46 mg gallic acid equivalents (GAE)/100 g of extract. The overall findings suggested that different part of feijoa (especially leaves and peel) could be used as a natural antibacterial and antioxidant for functional foods.
\end{abstract}

Keywords: Antioxidant activity, Antibacterial activity, Plant extract, Total phenolic content, Feijoa sellowiana

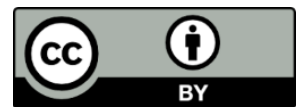

(C) 2021 The Author(s)

Available online at

http://jfhs.scientificwebjournals.com 


\section{Introduction}

In the last decades, there has been a growing interest in the use of natural additives in foods and cosmetics worldwide due to the growing concern among consumers about potential toxicological effects of synthetic antioxidants (Chew et al., 2012). Plants are one of the most important sources of natural additives because of their antioxidant and antimicrobial agents (Basile et al., 1997). Also, plants are important part of the human diet and they have been used for thousands of years in traditional medicine and to enhance the flavor, aroma and color of foods (Neilsen and Rios, 2000). Due to these important properties of plants, scientific studies are ongoing to search for new antioxidants and antimicrobial substances from various plant sources.

The feijoa (Feijoa sellowiana, synonym Acca sellowiana) belongs to the Myrtaceae family and commonly known as guavasteen or pineapple guava, is a subtropical species whose fruits are used for human nutrition. Feijoa is originally native to South America; it is well acclimatized to some other parts of the world such as USA, Turkey, Italy, France, Australia, New Zealand and Iran (Zhu et al., 2018). The fruit is an evergreen shrub and its pulp has sweet granular, acidulous and aromatic flesh with seeds embedded in a jelly located in the central. However, the peel is green, smooth, bitter, and sour. In addition to its sweet aromatic fruits, thanks to its pleasant taste and intense color, the petals of the flowers are being eaten, usually in sweets, salads and as dish decorations (Souza et al., 2016). Feijoa fruit is used to make ice cream, smoothie, juice, yogurt, puree, jam, wine, muffin, bread spread, chocolate, candy, smoothie, and wine (Sun-Waterhouse, 2011). Feijoa is a good source of vitamin C (28 $\mathrm{mg} / 100 \mathrm{~g}$ ), low in calories and high in minerals, iodine and fibre (Basile et al., 1997). Moreover, feijoa has high content of polyphenols, especially the flavonoids. It has been reported that $F$. sellowiana has various biological activities, such as antimicrobial, antioxidant (Basile et al., 1997; Beyhan et al., 2010; Elfarnini et al., 2018), antifungal (Vuotto et al., 2000), anti-inflammatory (Rossi et al., 2007), anticancer (Bontempo et al., 2007) and immunity-stimulating (Lapcik et al., 2005) activities due to its composition rich in antioxidants flavonoids.

Food waste is a major problem facing humanity in environmental, economic and social terms. The Food and Agriculture Organization of the United Nations (FAO, 2015) reported that 1.3 billion tonnes (represent US\$ 1 trillion) of food intended for human consumption are wasted. Almost half (around $45 \%$ ) of the vegetables and fruits produced all over the world are wasted and thus discarding bioactive compounds which have many health benefits, such as antioxidant, anticancer, antiviral, anti-inflammatory and others (Santos et al., 2019; Viganó et al., 2015). In this respect, in order to prevent this waste parts (such as leaves and peel) of the vegetables and fruits should be evaluated.

Different extraction techniques may be used to obtain fruit waste extracts. Water, ethanol, methanol, propanol, acetone, and ethyl acetate and their combinations are commonly used as solvents for phenolic compound extraction (Aires, 2017). The conditions for extraction in the herbal food and medical industries can influence the isolation and characterization of compounds. In fact, the variations in composition and antioxidant activity are related to technical practices in various laboratories (Yakoub et al., 2018). It is well known that the determination of polyphenolic compounds is affected by their chemical nature, the extraction technique/method used, sample molecule size and stocking time, period and conditions, as well as the assay method (Poodi et al., 2018; Tanko et al., 2005).

Although many researchers have focused on determining the antimicrobial and antioxidant activity of feijoa (Basile et al., 1997; Vuotto et al., 2000; Beyhan et al., 2010; Tuncel and Y1lmaz, 2015; Mosbah et al., 2018; Santos et al., 2019) little information is available about the effect of different extraction methods and conditions on total phenolic content, antimicrobial and antioxidant activities of extracts obtained from different parts of feijoa. The aim of the present study was to obtain extracts from feijoa leaves, peel and pulp by means of different extraction techniques, solvents and extract concentrations, and to compare them in terms of total phenolic content, antibacterial and antioxidant activities.

\section{Materials and Methods}

\section{Plant Material}

The fresh feijoa (Feijoa sellowiana) were collected from Sürmene county of Trabzon, Turkey. The mean weight and length of feijoa were $27.72 \pm 4.60 \mathrm{~g}$ and $51.73 \pm 5.76 \mathrm{~mm}$, respectively. The plants for extraction were segregated into three parts consisting of the pulp, peel and leaves.

\section{Extracts Preparation}

For extraction purpose, the feijoa pulp, peel and leaves were dried in a drying oven (Pol-Eko-Aparatura sp. J., Poland) at $40{ }^{\circ} \mathrm{C}$ for $24 \mathrm{~h}$ and finely ground (18-20 mesh) using a blade mixer to produce a powder that can pass through an 18 mesh stainless steel sieve. After the drying process, total weight of pulp, peel and leaves decreased $80.11 \%, 78.89 \%$ and $45.79 \%$, respectively. All the plants parts were extracted in $50 \mathrm{~mL}$ beakers with different extraction techniques (ultrasound-assisted extraction and shaking water bath extraction), solvents 
(ethanol, acetone and distilled water) and concentration $(2.5 \%$ and $5 \%)$. The shaking water bath extraction was conducted in a shaking water bath for $24 \mathrm{~h}$ at $40{ }^{\circ} \mathrm{C}$. For ultrasound-assisted extraction (UAE), the mixture was dispersed by ultrasonication using a Vibra-Cell Ultrasonic Processor (Model VC505, Sonics and Materials, Inc., USA) standard probe at $20 \mathrm{kHz}$ for $20 \mathrm{~min}$. All extracts were filtered through Whatman filter paper grade 1 for both extraction methods. The collected filtrate of extracts obtained with ethanol and acetone solvents was placed in a rotary evaporator under reduced pressure and controlled temperature $\left(50{ }^{\circ} \mathrm{C}\right.$ for acetone and $70{ }^{\circ} \mathrm{C}$ for ethanol) for evaporation to dryness to remove the solvent. The final residue was re-dissolved in water using ultrasonic bath to obtain a final concentration of $50 \mathrm{~mL}$. However, the samples extracted with water were not evaporated using a rotary evaporator. All extracts were then stored at $-80{ }^{\circ} \mathrm{C}$ until analysis. Detailed information on extraction conditions and relative codes for all extracts was given in Table 1.

Table 1. Extraction conditions and relative codes for feijoa leaves, peel and pulp extracts

\begin{tabular}{lllc}
\hline Sample code & $\begin{array}{c}\text { Extraction } \\
\text { Techniques }\end{array}$ & Solvent & $\begin{array}{c}\text { Concentration } \\
\text { (\%) }\end{array}$ \\
\hline WB-E2.5\% & Shaking water bath Ethanol (80\%) & 2.5 \\
WB-E5\% & Shaking water bath Ethanol (80\%) & 5 \\
WB-A2.5\% & Shaking water bath Acetone (80\%) & 2.5 \\
WB-A5\% & Shaking water bath Acetone (80\%) & 5 \\
WB-W2.5\% & Shaking water bath Distilled Water & 2.5 \\
WB-W 5\% & Shaking water bath Distilled Water & 5 \\
U-E2.5\% & Ultrasound-assisted Ethanol (80\%) & 2.5 \\
U-E5\% & Ultrasound-assisted Ethanol (80\%) & 5 \\
U-A2.5\% & Ultrasound-assisted Acetone (80\%) & 2.5 \\
U-A5\% & Ultrasound-assisted Acetone (80\%) & 5 \\
U-W2.5\% & Ultrasound-assisted Distilled Water & 2.5 \\
U-W5\% & Ultrasound-assisted Distilled Water & 5 \\
\hline
\end{tabular}

\section{Determination of Total Phenolic Content}

Total phenolic content of feijoa leaves, peel and pulp extracts was measured using modified method of Singleton and Rossi (1965). Briefly from the stock solution of $(1 \mathrm{mg} / \mathrm{mL}$ methanol) $100 \mu \mathrm{L}$ of the extracts were made up to $3 \mathrm{~mL}$ with distilled water then mixed thoroughly with $250 \mu \mathrm{L}$ of Folin-Ciocalteu reagent for $3 \mathrm{~min}$, followed by the addition of $750 \mu \mathrm{L}$ of $20 \%(\mathrm{w} / \mathrm{v})$ sodium carbonate and $900 \mu \mathrm{L}$ distilled water. The mixture was incubated at $40{ }^{\circ} \mathrm{C}$ for $30 \mathrm{~min}$ in a water bath and absorbance of the reaction mixtures was measured at $760 \mathrm{~nm}$. Quantification was done on the basis of the standard curve of gallic acid concentration range from 100 to 800 $\mu \mathrm{g} / \mathrm{ml}\left(\mathrm{r}^{2}=0.992\right)$. Total phenolic content calculated from the calibration curve was expressed as $\mathrm{mg}$ of gallic acid equivalent (GAE)/g of extract.

\section{Antioxidant Activity}

\section{(2, 2-diphenyl-1-picrylhydrazyl (DPPH))}

The radical scavenging activity of the plant extracts was tested against 2,2-diphenyl-1-picryl-hydrazyl radical following the method described by Brand-Williams et al. (1995) with slight modification. $100 \mu \mathrm{L}$ of each plant extract was mixed with $3.9 \mathrm{ml}$ DPPH working solution in test tubes. Then the mixture was vortexed and the tubes incubated in dark for $60 \mathrm{~min}$. The absorbance was read at $515 \mathrm{~nm}$ using a spectrophotometer (Shimadzu UV-1208, Japan). A blank solution containing the same amount of methanol and DPPH was prepared and measured. All the measurements were taken in triplicate and the mean values calculated. The radical scavenging activity was calculated using the following equation:

$$
\text { DPPH scavenging effect }(\%)=\frac{(\text { Ablank }- \text { Aextract })}{\text { Ablank }} \times 100
$$

\section{Microorganism}

Four Gram-negative bacteria strains (Escherichia coli ATCC 25922, Salmonella enterica ATCC 13076, Aeromonas hydrophila ATCC 7966 and Aeromonas sobria ATCC 43979) and one Gram-positive strain (Staphylococcus aureus ATCC 25923) were used for antibacterial activity of the extracts. The pure cultures were stored in cryogenic vials with $30 \%$ (w/w) glycerol in Tryptic Soy Broth (TSB) at $-80{ }^{\circ} \mathrm{C}$.

\section{Antimicrobial Screening by Disk Diffusion Technique}

All of the bacterial strains were grown overnight on Mueller Hinton Agar (MHA) at $37^{\circ} \mathrm{C}$. The bacteria were suspended in sterile physiologic normal saline $(0.9 \% \mathrm{NACI})$ and adjusted to the $0.5 \mathrm{McF}$ arland's standard. $20 \mu \mathrm{L}$ of the extracts were impregnated into sterile paper discs $(6 \mathrm{~mm}$ diameter $)$ and the paper discs were allowed to air dry under in a laminar hood for $30 \mathrm{~min}$. Then discs were placed on the MHA surface previously inoculated with a sterile swab containing a suspension of each type of microorganism. Also, deionized water-loaded disc was used as negative control. Plates were incubated at $37^{\circ} \mathrm{C}$ for $24 \mathrm{~h}$ for $E$. coli, S. enterica and $S$. aureus and $30^{\circ} \mathrm{C}$ for $24 \mathrm{~h}$ for $A$. hydrophila and A. sobria. The inhibition zones around the disk were measured and recorded at the end of the incubation period.

\section{Statistical Analysis}

Results were expressed as the means and standard deviations. Statistical comparisons between extracts were performed with variance (ANOVA) and TUKEY test. Differences were considered significant at $P<0.05$. Statistical analyses were conducted using JMP 5.0.1 (SAS Institute, Inc., Cary, NC, USA) software. All tests were performed in triplicate. 


\section{Results and Discussion}

\section{Antibacterial Activity}

The disk diffusion method was used to determine the antibacterial effect of leaves, peel and pulp extracts of feijoa against four Gram-negative (A. sobria, A. hydrophila, E. coli, S. enterica) and one Gram-positive (S. aureus) pathogen bacteria. Antibacterial activity results of extracts from the different parts of feijoa were given in Table 2 .

Table 2. Antibacterial activity against pathogen bacteria of leaves, peel and pulp extracts of Feijoa sellowiana

\begin{tabular}{|c|c|c|c|c|}
\hline \multirow{2}{*}{ Microorganism } & \multirow{2}{*}{ Extracts } & \multicolumn{3}{|c|}{ Inhibitions zone (mm) } \\
\hline & & Leaves & Peel & Pulp \\
\hline A. sobria & $\begin{array}{l}\text { WB-E2.5\% } \\
\text { WB-E5\% } \\
\text { WB-A2.5\% } \\
\text { WB-A5\% } \\
\text { WB-W2.5\% } \\
\text { WB-W5\% } \\
\text { U-E2.5\% } \\
\text { U-E5\% } \\
\text { U-A2.5\% } \\
\text { U-A5\% } \\
\text { U-W2.5\% } \\
\text { U-W5\% }\end{array}$ & $\begin{array}{l}\mathrm{NI}^{\mathrm{E}} \\
7.61 \pm 0.35^{\mathrm{Da}} \\
7.45 \pm 0.03^{\mathrm{Da}} \\
9.19 \pm 0.11^{\mathrm{Ca}} \\
7.42 \pm 0.03^{\mathrm{Da}} \\
10.26 \pm 0.11^{\mathrm{Ba}} \\
\mathrm{NI}^{\mathrm{E}} \\
7.94 \pm 0.07^{\mathrm{Da}} \\
7.66 \pm 0.06^{\mathrm{Da}} \\
9.04 \pm 0.23^{\mathrm{Ca}} \\
7.31 \pm 0.01^{\mathrm{Da}} \\
12.14 \pm 0.45^{\mathrm{Aa}}\end{array}$ & $\begin{array}{l}\mathrm{NI}^{\mathrm{D}} \\
\mathrm{NI}^{\mathrm{Db}} \\
\mathrm{NI}^{\mathrm{Db}} \\
7.69 \pm 0.11^{\mathrm{Cb}} \\
\mathrm{NI}^{\mathrm{Db}} \\
9.27 \pm 0.37^{\mathrm{Ab}} \\
\mathrm{NI}^{\mathrm{D}} \\
\mathrm{NI}^{\mathrm{Db}} \\
\mathrm{NI}^{\mathrm{Db}} \\
8.36 \pm 0.15^{\mathrm{Bb}} \\
\mathrm{NI}^{\mathrm{Db}} \\
7.92 \pm 0.01^{\mathrm{BCb}}\end{array}$ & $\begin{array}{l}\mathrm{NI}^{\mathrm{B}} \\
\mathrm{NI}^{\mathrm{Bb}} \\
\mathrm{NI}^{\mathrm{Bb}} \\
\mathrm{NI}^{\mathrm{Bc}} \\
\mathrm{NI}^{\mathrm{Bb}} \\
6.75 \pm 0.08^{\mathrm{Ac}} \\
\mathrm{NI}^{\mathrm{B}} \\
\mathrm{NI}^{\mathrm{Bb}} \\
\mathrm{NI}^{\mathrm{Bb}} \\
\mathrm{NI}^{\mathrm{Bc}} \\
\mathrm{NI}^{\mathrm{Bb}} \\
\mathrm{NI}^{\mathrm{Bc}}\end{array}$ \\
\hline \multirow{12}{*}{ A. hydrophila } & WB-E2.5\% & $7.46 \pm 0.20^{\mathrm{Ba}}$ & $\mathrm{NI}^{\mathrm{Db}}$ & $\mathrm{NI}^{\mathrm{b}}$ \\
\hline & WB-E5\% & $8.21 \pm 0.13^{\mathrm{Ba}}$ & $\mathrm{NI}^{\mathrm{Db}}$ & $\mathrm{NI}^{\mathrm{b}}$ \\
\hline & WB-A2.5\% & $7.89 \pm 0.56^{\mathrm{Ba}}$ & $\mathrm{NI}^{\mathrm{Db}}$ & $\mathrm{NI}^{\mathrm{b}}$ \\
\hline & WB-A5\% & $9.82 \pm 0.13^{\mathrm{Aa}}$ & $7.42 \pm 0.06^{\mathrm{Cb}}$ & $\mathrm{NI}^{\mathrm{c}}$ \\
\hline & WB-W2.5\% & $7.36 \pm 0.07^{\mathrm{Ba}}$ & $\mathrm{NI}^{\mathrm{Db}}$ & $\mathrm{NI}^{\mathrm{b}}$ \\
\hline & WB-W5\% & $8.20 \pm 0.16^{\mathrm{Ba}}$ & $7.84 \pm 0.01^{\mathrm{Ba}}$ & $\mathrm{NI}^{\mathrm{b}}$ \\
\hline & U-E2.5\% & $\mathrm{NI}^{\mathrm{C}}$ & $\mathrm{NI}^{\mathrm{D}}$ & $\mathrm{NI}$ \\
\hline & U-E5\% & $\mathrm{NI}^{\mathrm{C}}$ & $\mathrm{NI}^{\mathrm{D}}$ & $\mathrm{NI}$ \\
\hline & $\mathrm{U}-\mathrm{A} 2.5 \%$ & $7.51 \pm 0.12^{\mathrm{Ba}}$ & $\mathrm{NI}^{\mathrm{Db}}$ & $\mathrm{NI}^{\mathrm{b}}$ \\
\hline & U-A $5 \%$ & $9.23 \pm 0.27^{\mathrm{Aa}}$ & $8.24 \pm 0.13^{\mathrm{Ab}}$ & $\mathrm{NI}^{\mathrm{c}}$ \\
\hline & U-W2.5\% & $7.92 \pm 0.04^{\mathrm{Ba}}$ & $\mathrm{NI}^{\mathrm{Db}}$ & $\mathrm{NI}^{\mathrm{b}}$ \\
\hline & U-W5\% & $9.39 \pm 0.35^{\mathrm{Aa}}$ & $7.88 \pm 0.11^{\mathrm{Bb}}$ & $\mathrm{NI}^{\mathrm{c}}$ \\
\hline \multirow{11}{*}{ E. coli } & WB-E2.5\% & $\mathrm{NI}^{\mathrm{E}}$ & $\mathrm{NI}^{\mathrm{D}}$ & NI \\
\hline & WB-E5\% & $7.61 \pm 0.04^{\mathrm{CDa}}$ & $\mathrm{NI}^{\mathrm{Db}}$ & $\mathrm{NI}^{\mathrm{b}}$ \\
\hline & WB-A2.5\% & $7.56 \pm 0.04^{\mathrm{Da}}$ & $\mathrm{NI}^{\mathrm{Db}}$ & $\mathrm{NI}^{\mathrm{b}}$ \\
\hline & WB-A5\% & $8.83 \pm 0.22^{\mathrm{Aa}}$ & $6.82 \pm 0.04^{\mathrm{Cb}}$ & $\mathrm{NI}^{\mathrm{c}}$ \\
\hline & WB-W2.5\% & $\mathrm{NI}^{\mathrm{E}}$ & $\mathrm{NI}^{\mathrm{D}}$ & $\mathrm{NI}$ \\
\hline & WB-W5\% & $8.09 \pm 0.29^{\mathrm{BCa}}$ & $\mathrm{NI}^{\mathrm{Db}}$ & $\mathrm{NI}^{\mathrm{b}}$ \\
\hline & U-E2.5\% & $\mathrm{NI}^{\mathrm{E}}$ & $\mathrm{NI}^{\mathrm{D}}$ & $\mathrm{NI}$ \\
\hline & U-E5\% & $\mathrm{NI}^{\mathrm{E}}$ & $\mathrm{NI}^{\mathrm{D}}$ & NI \\
\hline & U-A2.5\% & $\mathrm{NI}^{\mathrm{E}}$ & $\mathrm{NI}^{\mathrm{D}}$ & NI \\
\hline & U-A5\% & $8.31 \pm 0.01^{\mathrm{Ba}}$ & $7.81 \pm 0.15^{\mathrm{Ab}}$ & $\mathrm{NI}^{\mathrm{c}}$ \\
\hline & $\begin{array}{l}\text { U-W2.5\% } \\
\text { U-W5\% }\end{array}$ & $\begin{array}{l}7.52 \pm 0.14^{\mathrm{Da}} \\
8.87 \pm 0.15^{\mathrm{Aa}}\end{array}$ & $\begin{array}{l}\mathrm{NI}^{\mathrm{Db}} \\
7.51 \pm 0.07^{\mathrm{Bb}}\end{array}$ & $\begin{array}{l}\mathrm{NI}^{\mathrm{b}} \\
\mathrm{NI}^{\mathrm{c}}\end{array}$ \\
\hline \multirow{11}{*}{ S. enterica } & WB-E2.5\% & $7.43 \pm 0.03^{\mathrm{Da}}$ & $\mathrm{NI}^{\mathrm{Db}}$ & $\mathrm{NI}^{\mathrm{Bb}}$ \\
\hline & WB-E5\% & $7.79 \pm 0.11^{\mathrm{CDa}}$ & $\mathrm{NI}^{\mathrm{Db}}$ & $\mathrm{NI}^{\mathrm{Bb}}$ \\
\hline & WB-A2.5\% & $8.26 \pm 0.55^{\mathrm{BCDa}}$ & $\mathrm{NI}^{\mathrm{Db}}$ & $\mathrm{NI}^{\mathrm{Bb}}$ \\
\hline & WB-A5\% & $9.63 \pm 0.41^{\mathrm{Aa}}$ & $8.42 \pm 0.07^{\mathrm{Bb}}$ & $6.98 \pm 0.23^{\mathrm{Ac}}$ \\
\hline & WB-W2.5\% & $7.47 \pm 0.17^{\mathrm{Da}}$ & $\mathrm{NI}^{\mathrm{Db}}$ & $\mathrm{NI}^{\mathrm{Bb}}$ \\
\hline & WB-W5\% & $7.88 \pm 0.42^{\mathrm{CDb}}$ & $9.88 \pm 0.13^{\mathrm{Aa}}$ & $7.01 \pm 0.13^{\mathrm{Ab}}$ \\
\hline & U-E2.5\% & $\mathrm{NI}^{\mathrm{Ea}}$ & $\mathrm{NI}^{\mathrm{Da}}$ & $\mathrm{NI}^{\mathrm{Ba}}$ \\
\hline & U-E5\% & $\mathrm{NI}^{\mathrm{Ea}}$ & $\mathrm{NI}^{\mathrm{Da}}$ & $\mathrm{NI}^{\mathrm{Ba}}$ \\
\hline & U-A $2.5 \%$ & $7.65 \pm 0.09^{\mathrm{CDa}}$ & $7.68 \pm 0.10^{\mathrm{Ca}}$ & $\mathrm{NI}^{\mathrm{Bb}}$ \\
\hline & U-A $5 \%$ & $8.94 \pm 0.06^{\mathrm{ABa}}$ & $8.31 \pm 0.07^{\mathrm{Bb}}$ & $6.83 \pm 0.01^{\mathrm{Ac}}$ \\
\hline & $\begin{array}{l}\text { U-W2.5\% } \\
\text { U-W5\% }\end{array}$ & $\begin{array}{l}8.11 \pm 0.16^{\mathrm{BCDa}} \\
8.56 \pm 0.16^{\mathrm{BCa}}\end{array}$ & $\begin{array}{l}7.59 \pm 0.04^{\mathrm{Ca}} \\
7.83 \pm 0.05^{\mathrm{Cb}}\end{array}$ & $\begin{array}{l}\mathrm{NI}^{\mathrm{Bb}} \\
6.96 \pm 0.08^{\mathrm{Ac}}\end{array}$ \\
\hline
\end{tabular}


Table 2 continuing

\begin{tabular}{lllll}
\hline WB-E2.5\% & $\mathrm{NI}^{\mathrm{D}}$ & $\mathrm{NI}^{\mathrm{C}}$ & $\mathrm{NI}^{\mathrm{B}}$ \\
WB-E5\% & $7.67 \pm 0.06^{\mathrm{Ca}}$ & $\mathrm{NI}^{\mathrm{Cb}}$ & $\mathrm{NI}^{\mathrm{Bb}}$ \\
& WB-A2.5\% & $7.54 \pm 0.17^{\mathrm{Ca}}$ & $\mathrm{NI}^{\mathrm{Cb}}$ & $\mathrm{NI}^{\mathrm{Bb}}$ \\
WB-A5\% & $9.52 \pm 0.04^{\mathrm{Ba}}$ & $7.38 \pm 0.11^{\mathrm{Bb}}$ & $\mathrm{NI}^{\mathrm{Bc}}$ \\
WB-W2.5\% & $\mathrm{NI}^{\mathrm{D}}$ & $\mathrm{NI}^{\mathrm{C}}$ & $\mathrm{NI}^{\mathrm{B}}$ \\
& WB-W5\% & $8.29 \pm 0.22^{\mathrm{Ca}}$ & $7.97 \pm 0.24^{\mathrm{Aa}}$ & $\mathrm{NI}^{\mathrm{Bb}}$ \\
$\mathrm{U}-\mathrm{E} 2.5 \%$ & $\mathrm{NI}^{\mathrm{Da}}$ & $\mathrm{NI}^{\mathrm{Ca}}$ & $6.45 \pm 0.25^{\mathrm{Ab}}$ \\
$\mathrm{U}-\mathrm{N} \%$ & $\mathrm{NI}^{\mathrm{Da}}$ & $\mathrm{NI}^{\mathrm{Ca}}$ & $6.35 \pm 0.03^{\mathrm{Ab}}$ \\
$\mathrm{U}-\mathrm{A} 2.5 \%$ & $7.97 \pm 0.11^{\mathrm{Ca}}$ & $7.67 \pm 0.16^{\mathrm{ABa}}$ & $6.46 \pm 0.06^{\mathrm{Ab}}$ \\
$\mathrm{U}-\mathrm{A} 5 \%$ & $10.14 \pm 0.47^{\mathrm{ABa}}$ & $7.75 \pm 0.22^{\mathrm{ABb}}$ & $\mathrm{NI}^{\mathrm{Bc}}$ \\
$\mathrm{U}-\mathrm{W} 2.5 \%$ & $8.23 \pm 0.33^{\mathrm{Ca}}$ & $7.33 \pm 0.01^{\mathrm{Bb}}$ & $\mathrm{NI}^{\mathrm{Bc}}$ \\
$\mathrm{U}-\mathrm{W} 5 \%$ & $10.82 \pm 0.13^{\mathrm{Aa}}$ & $7.74 \pm 0.25^{\mathrm{ABb}}$ & $6.63 \pm 0.24^{\mathrm{Ac}}$ \\
\hline
\end{tabular}

For each pathogen, different capital superscript letters in the same column represent significant differences $(P<0.05)$ among the different extracts in the same part of feijoa. Different lower case superscript letters in the same line represent significant differences $(P<0.05)$ among the same extracts in the different part of feijoa. NI: No inhibition.

The antibacterial effect against $A$. sobria of the leaves extracts was higher than those of peel and pulp extracts $(P<0.05)$. The leaves extracts except for WB-E2.5\% and UE2.5\% had inhibition zone on A. sobria. The WB-A5\%, WB$\mathrm{W} 5 \%, \mathrm{U}-\mathrm{A} 5 \%$ and $\mathrm{U}-\mathrm{W} 5 \%$ extracts from peel showed antibacterial activity against $A$. sobria, however only WB-W5\% extract from pulp had an antibacterial activity against $A$. sobria. According to the results, the antibacterial activity against $A$. sobria and $A$. hydrophila of extracts prepared with water and acetone were higher than ethanolic extracts which have same concentration and extract method. The extracts from the leaves against both bacteria had greater antibacterial properties than the peel and pulp extracts $(P<0.05)$. In particular, the WB-A $5 \%$, WB-W5\%, U-A $5 \%$ and U-W5\% extracts possessed the greatest antibacterial activity against $A$. hydrophila $(P<0.05)$. The pulp extracts had no antibacterial activity against $A$. hydrophila. WB-A5\% and U-W5\% extracts from leaves showed statistically higher value than other extracts from leaves, peel and pulp $(P<0.05)$. As shown in Table 2 , the WB-A5\%, WB-W5\%, U-A $5 \%$ and U-W5\% extracts were more effective $(P<0.05)$ in inhibiting growth of $E$. coli than other extracts from leaves, peel and pulp. No antibacterial activity against $E$. coli was determined in pulp extracts. The maximal inhibitions were observed at $5 \%$ for $S$. enterica and the maximum inhibition zone of leaves, peel and pulp extracts was determined as $9.63 \mathrm{~mm}, 9.88 \mathrm{~mm}$ and $7.01 \mathrm{~mm}$, respectively. On the other hand, the extracts of leaves except for U-E2.5\% and U-E5\% exhibited the activity on S. enterica compared to peel and pulp extracts $(P<0.05)$. Extracts of pulp at $2.5 \%$ concentration did not shown any antibacterial activity against $S$. enterica. The maximum inhibition zone of feijoa extracts against $S$. aureus was found in U-W5\% $(10.82 \mathrm{~mm})$ of leaves, WB-W5\% $(7.97 \mathrm{~mm})$ of peel and U-W5\% (6.63 $\mathrm{mm}$ ) of pulp. Only WB-A5\% and WB-W5\% extracts obtained from peel by water bath method had inhibitory effect on $S$. aureus while none of the extracts from pulp by water bath method exhibited the activity on $S$. aureus. According to the results, the ultrasonic method was more effective than the water bath method in preventing the growth of $S$. aureus.

This study determined that concentration of extract is an important parameter on antibacterial activity of extracts. According to the results, the $5 \%$ concentrations of all extracts were more effective than the $2.5 \%$ to inhibit the growth of pathogenic bacteria tested in the present study $(P<0.05)$. In general, WB-A $5 \%$, WB-W5\%, U-A5\% and U-W5\% extracts of feijoa leaves, peel and pulp on all tested pathogen bacteria were found to be comparatively higher than other extracts $(P<0.05)$. The highest inhibition zone of the leaves, peel and pulp extracts was determined in U-W5\% (12.14 mm) against A. sobria, WB-A5\% $(9.82 \mathrm{~mm})$ against $A$. hydrophila, UW5\% $(8.87 \mathrm{~mm})$ against $E$. coli, WB-W5\% (9.88 mm) against $S$. enterica and U-W5\% (10.82 mm) against $S$. aureus. The pulp extracts did not exert visible effect on growth of $A$. hydrophila and E. coli while WB-A5\%, WB-W5\%, UA $5 \%$ and U-W5\% extracts from pulp showed inhibitory effect against $S$. enterica. Also, the antibacterial activity of extracts from different part of feijoa against both tested Grampositive and Gram-negative strains was determined as leaves $>$ peel $>$ pulp. Similarly, Phan et al. (2019) reported that the methanolic extracts from different tissues of Australian grown feijoa have the stronger antimicrobial activity than the water extracts against $E$. coli, $S$. aureus and $C$. albians and the inhibition zones of the methanolic extracts against the three microorganisms were between 11.9-23.4 mm. Also, they determined that peel extracts had higher antibacterial activity than those of pulp and whole fruit. Vuotto et al. (2000) reported that feijoa aquatic extracts showed inhibition against all bacteria strains tested and MIC of the extracts were between 1-64 mg/L. Also, they determined that Gram-negative bacteria were more sensitive to the extracts than Gram-positive bacteria. Conversely, Basile et al. (1997) reported that the antimicrobial activity of extracts from fruit (Feijoa sel- 
lowiana, Actinidia chinensis, and Aberia caffra) was generally more active that extracts from vegetative plant parts. The mode of antimicrobial action of feijoa extracts depends on the types of bacteria with respect to the cell wall structure. Grampositive bacteria contain an outer peptidoglycan layer, which is an ineffective permeability barrier (Baba and Malik, 2014; Karsli et al., 2019). Also, the inhibitory activity of the plant extracts against the bacteria might be due to iron deprivation or hydrogen bonding with vital proteins needed for the growth of the bacteria (Scalbert, 1991). In addition, Safari and Ahmady-Asbchin (2019) reported that the antibacterial activity of the extract could be attributed to the high content of phenols and flavonoids. In the present study, we also determined that the extracts with higher phenolic content had higher antibacterial activity against tested pathogen bacteria. In this regard, feijoa leaves and peel extracts showed stronger antimicrobial efficacy than pulp extracts, which is well associated with our observation that feijoa leaves and peel have a higher total phenolic content than pulp.

\section{Antioxidant Activity}

The antioxidant activity of leaves, peel and pulp extracts of $F$. sellowiana was evaluated by the DPPH radical scavenging method and the results are shown in Figure 1. The feijoa fruit and leaves have high levels of antioxidants since they contain high levels of polyphenols (Beyhan et al., 2010). In the present study, the extracts of the leaves, peel and pulp had DPPH radical scavenging activity between $85.78-90.82 \%$, 89.86$91.60 \%$ and $81.49-91.31 \%$, respectively. The peel extracts demonstrated comparatively stronger antioxidant activity compared to the leaves and pulp extracts. Similarly, Peng et al. (2019) reported that antioxidant activity of New Zealand grown feijoa peel extracts were significantly higher than the whole fruit and flesh extracts. Amarante et al. (2017) reported that the feijoa peel extracts exhibited stronger antioxidant activity than the flesh extracts. In the present study, it was observed that antioxidant activity of the feijoa extracts increased with increasing the concentration of extracts and DPPH radical scavenging activity of 5\% extracts were higher than $2.5 \%$ extracts. Turkmen et al. (2006) reported that the effect of solvent type is related to polarity of the solvents and the solubility of target compounds in them. In the present study, solvent type also had significant impact on the antioxidant capacities of feijoa leaves extracts. Indeed, the extraction with water showed the lowest scavenging activity compared to the extraction with ethanol and acetone $(P<0.05)$. In terms of extraction efficiency, no significant differences were observed between acetone and ethanol used for extraction of different parts of feijoa except for pulp $(P>0.05)$. Tuncel and Yilmaz (2015) reported that the acetonic $(80 \%)$ feijoa extracts have higher antioxidant activity than methanolic and ethanolic extracts. In this study, significant differences were also observed among the extracts from different part of feijoa and the different extracts from same part of feijoa $(P<0.05)$. However, no statistical difference $(P<0.05)$ was observed between the extraction methods (ultrasonic and water bath extractions). The antioxidant activity of feijoa extracts may be linked to the presence of various bioactive compounds such as polyphenols and vitamin C (Cai et al., 2006).

\section{Total Phenolic Content}

The total phenols contents (TPC) of feijoa leaves, peel and pulp extracts are presented in Table 3 . Leaves extracts had significantly $(P<0.05)$ higher TPC than the peel and pulp extracts, while pulp extracts possessed the lowest TPC. In the present study, TPC of pulp extracts was approximately two to three times less than that of the leaves and peel. Similarly, Tuncel and Y1lmaz (2015) reported that TPC of the peel was approximately two - three folds than that of the flesh. The peel of feijoa fruit contains a higher total phenolic content than flesh (Amarante et al., 2017). In this study, min and max TPC of leaves, peel and pulp extracts was between 459.44$554.00,349.17-517.19$, and 115.64-345.46 mg GAE/100 g of extract, respectively. TPC of leaves extracts showed significant difference between ultrasound-assisted extraction (USE) and shaking water bath extraction (WBE) $(P<0.05)$. TPC value of acetonic and water extracts of leaves obtained by USE were higher than those of WBE, while TPC of ethanolic leaves extracts obtained by USE was lower than those of WBE. However, TPC value of peel and pulp extracts obtained by USE were lower than those of WBE except for WBE2.5\% and WB-A2.5\% of peel and WB-A2.5\% of pulp. Solvents used for total phenolic extraction also significantly $(P<0.05)$ affected the total phenolic concentration of feijoa extracts at equal volume of solvent. Water and acetone were more effective in extracting phenolic compounds from feijoa leaves, peel and pulp than ethanol. In this respect, water can preferably be used to obtain more TPC from feijoa leaves, peel and pulp than other organic solvents. In addition, the concentration of extract was effective on the TPC of feijoa extracts and TPC of 5\% extracts was generally higher than $2.5 \%$ extracts. The total phenolic concentration, antioxidant and antimicrobial activities observed in extracts of feijoa and its different parts were positively correlated, which is consistent with numerous studies. Pasquariello et al. (2015) reported that TPC of 12 feijoa cultivars fruits in Italy is between 92.88-251.02 mg GAE/100 g FW). Cecilia et al. (2016) reported that TPC of fresh fruit from 14 feijoa genotypes of Uruguay is between 197-359 mg GAE/100 g, FW. Weston (2010) has reported $59 \mathrm{mg}$ of TPC in $100 \mathrm{~g}$ of feijoa fruit. Tuncel and Y1lmaz (2015) reported that TPC of feijoa flesh 
extracted with ethanol, methanol and mixture was found in the range of 767 to $1856 \mathrm{mg} \mathrm{GAE} / 100 \mathrm{~g} \mathrm{dw}$. Beyhan et al. (2010) reported that TPC of leaf, dry fruit and fresh fruit of feijoa was $68.69,8.69$ and $17.68 \mu \mathrm{g} \mathrm{GAE} / \mathrm{mg}$, respectively. Mosbah et al. (2019) reported that TPC of feijoa leaves is 948 $\mathrm{mg} / 100 \mathrm{~g}$ extract. The results of the present study are higher than the reported values of Pasquariello et al. (2015), Cecilia et al. (2016) and Weston (2010), however lower than the values reported by Tuncel and Y1lmaz (2015), Beyhan et al. (2010) and Mosbah et al. (2019). The variation of results probably due to the plant variety, extraction techniques, type of solvent, geographical condition and the fruit size.

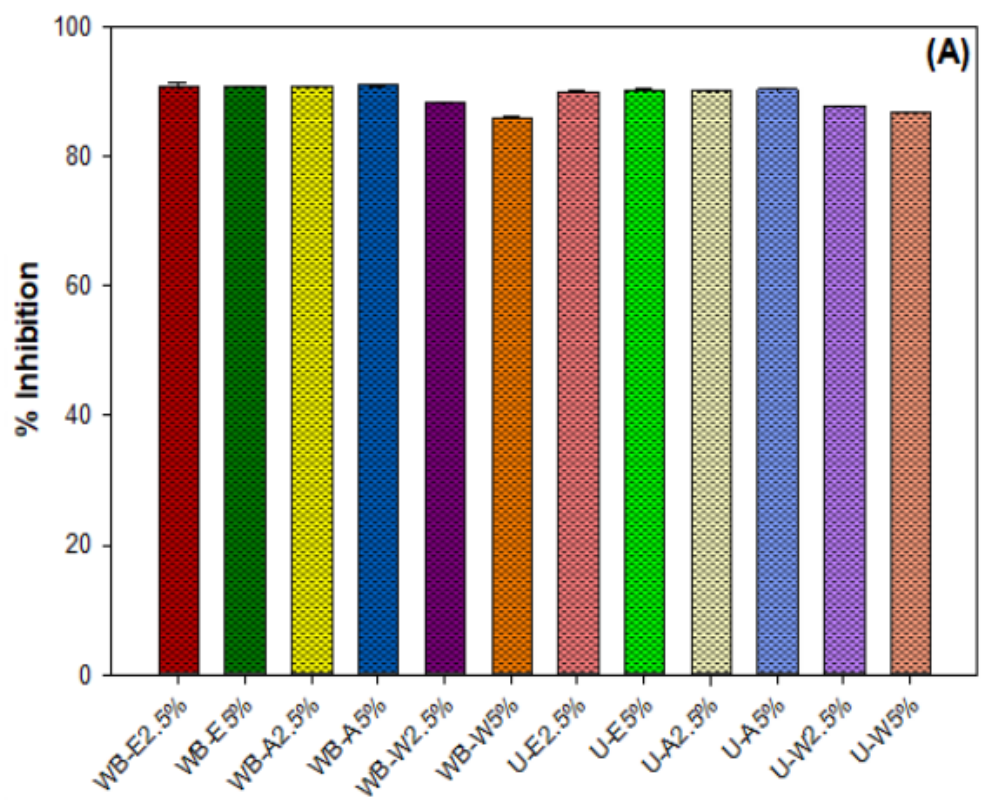

Samples

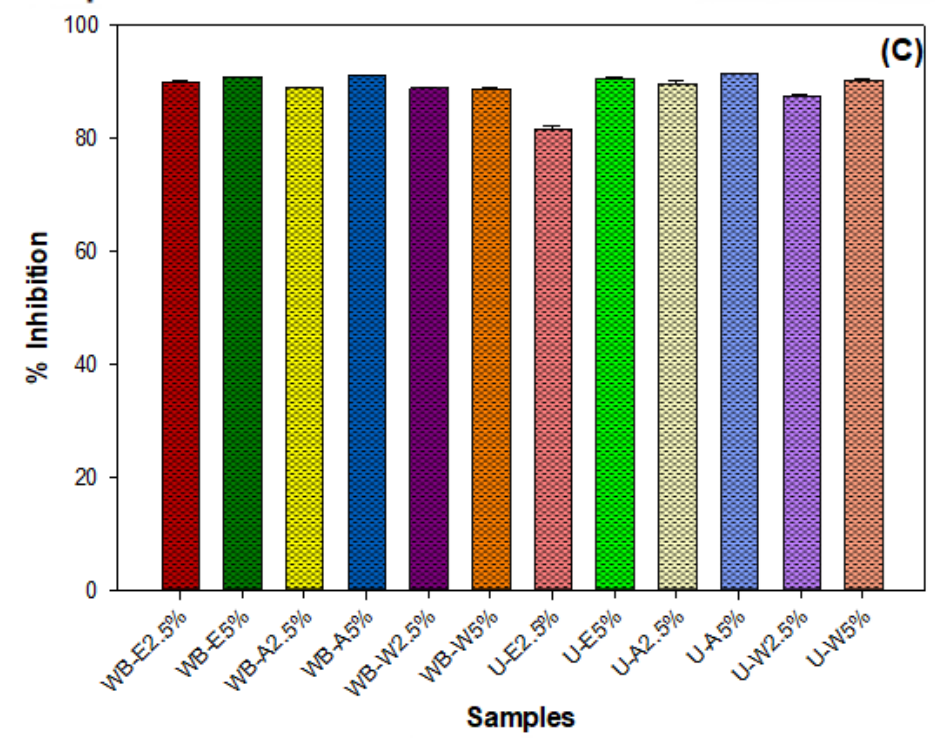

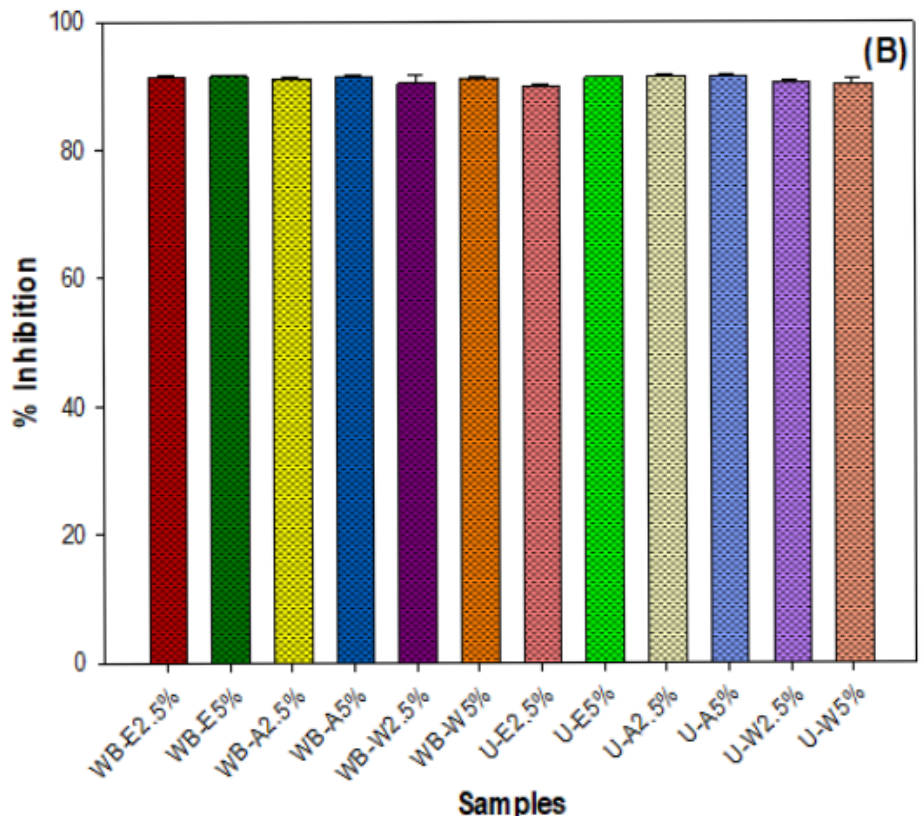

Samples 
Table 3. The total phenolic contents of feijoa leaves, peel and pulp extracts

\begin{tabular}{|c|c|c|c|}
\hline Extracts & Leaves & Peel & Pulp \\
\hline WB-E2.5\% & $488.99 \pm 0.96_{\mathrm{F}}^{\mathrm{a}}$ & $351.20 \pm 3.34_{\mathrm{E}}^{\mathrm{b}}$ & $184.36 \pm 5.73_{\mathrm{DE}}^{\mathrm{c}}$ \\
\hline WB-E5\% & $503.34 \pm 1.67_{\mathrm{DEF}}^{\mathrm{a}}$ & $495.74 \pm 15.76_{\mathrm{AB}}^{\mathrm{a}}$ & $276.73 \pm 7.88_{B}^{b}$ \\
\hline WB-A $2.5 \%$ & $500.30 \pm 5.01_{\mathrm{EF}^{\mathrm{a}}}^{\mathrm{a}}$ & $365.72 \pm 11.46_{\mathrm{E}}^{\mathrm{b}}$ & $166.13 \pm 13.37 \mathrm{E}^{\mathrm{c}}$ \\
\hline WB-A $5 \%$ & $520.91 \pm 2.15_{\mathrm{BC}}{ }^{\mathrm{a}}$ & $511.62 \pm 9.55_{\mathrm{A}^{\mathrm{a}}}$ & $327.22 \pm 10.99_{A}^{b}$ \\
\hline WB-W2.5\% & $492.03 \pm 8.12_{\mathrm{F}}^{\mathrm{a}}$ & $517.19 \pm 12.18_{\mathrm{A}}{ }^{\mathrm{a}}$ & $222.70 \pm 0.24_{C}{ }^{b}$ \\
\hline WB-W5\% & $507.23 \pm 5.73_{\mathrm{CDE}^{\mathrm{a}}}$ & $514.99 \pm 3.34_{\mathrm{A}^{\mathrm{a}}}$ & $345.46 \pm 10.99_{\mathrm{A}}^{\mathrm{b}}$ \\
\hline U-E2.5\% & $460.11 \pm 1.19_{\mathrm{G}}^{\mathrm{a}}$ & $411.65 \pm 2.87_{\mathrm{D}}^{\mathrm{b}}$ & $115.64 \pm 1.67_{\mathrm{F}}^{\mathrm{c}}$ \\
\hline U-E5\% & $459.44 \pm 1.67_{\mathrm{G}}^{\mathrm{a}}$ & $349.17 \pm 8.12^{\mathrm{b}}$ & $202.94 \pm 5.25_{\mathrm{CD}}^{\mathrm{c}}$ \\
\hline U-A $2.5 \%$ & $503.17 \pm 1.91_{\mathrm{DEF}^{\mathrm{a}}}$ & $438.16 \pm 3.10_{\mathrm{CD}}^{\mathrm{b}}$ & $177.61 \pm 5.25_{\mathrm{DE}}^{\mathrm{c}}$ \\
\hline U-A $5 \%$ & $530.19 \pm 2.39_{\mathrm{B}}{ }^{\mathrm{a}}$ & $492.54 \pm 6.93_{\mathrm{AB}}^{\mathrm{b}}$ & $263.90 \pm 5.01_{\mathrm{B}}{ }^{\mathrm{c}}$ \\
\hline U-W $2.5 \%$ & $516.18 \pm 1.67_{\mathrm{BCD}}{ }^{\mathrm{a}}$ & $468.39 \pm 0,88_{\mathrm{BC}}{ }^{\mathrm{b}}$ & $162.24 \pm 2.15_{\mathrm{E}}^{\mathrm{c}}$ \\
\hline U-W5\% & $554.00 \pm 3.58_{\mathrm{A}^{\mathrm{a}}}$ & $442.72 \pm 18.63_{\mathrm{CD}}^{\mathrm{b}}$ & $271.50 \pm 6.21_{\mathrm{B}}{ }^{\mathrm{c}}$ \\
\hline
\end{tabular}

Different capital superscript letters in the same column represent significant differences $(P<0.05)$ among the different extracts in the same part of feijoa. Different lower case superscript letters in the same line represent significant differences $(P<0.05)$ among the same extracts in the different part of feijoa

\section{Conclusions}

The results of this study indicate that all part of feijoa was found to be an effective antioxidant (ranged from 81.49 to 91.31\%), however the peel extracts had slightly higher antioxidant activity compared to the leaves and pulp extracts. Also, solvent type showed significant impact on the antioxidant capacities of feijoa leaves extracts. In general, the ethanolic and acetonic extracts have slightly higher DPPH radical scavenging activity compared to the water extracts. The concentration of extract was effective on antibacterial and antioxidant activity of extracts and 5\% extracts had higher antibacterial and antioxidant activity than the $2.5 \%$ extracts. Water and acetone extracts were more effective than ethanol extracts in antibacterial activity and extraction of phenolic compounds. In particular, WB-A5\%, WB-W5\%, U-A5\% and UW5\% extracts from feijoa leaves, peel and pulp had relatively higher antibacterial activity against all pathogen bacteria tested than other extracts. The leaves extracts possess the highest total phenolic content as well as antibacterial activity. Feijoa are not only interesting sources for antioxidant and antibacterial activities but also potential sources of rich phenolic compounds. Total phenolic content of leaves and peel extracts was higher two - three folds than that of the pulp. The results suggest that feijoa leaves and peel might be used as a potential source of natural antibacterial and antioxidant agent for human health and industrial purposes.

\section{Compliance with Ethical Standard}

Conflict of interests: The authors declare that for this article they have no actual, potential or perceived the conflict of interests.

Ethics committee approval: Author declare that this study does not include any experiments with human or animal subjects.

Funding disclosure: -

Acknowledgments: -

Disclosure: -

\section{References}

Aires, A. (2017). Phenolics in foods: extraction, analysis and measurements. In: M. Soto-Hernandez, M. Palma-Tenango \& R. Garcia-Mateos, (Eds), Phenolic compounds-natural sources, importance and applications (p. 61-88), London, UK: InTech. ISBN 978-953-51-2958-5

https://doi.org/10.5772/66889

Amarante, C.V.T., Souza, A.G., Benincá, T.D.T., Steffens, C.A. (2017). Phenolic content and antioxidant activity of fruit of Brazilian genotypes of feijoa. Pesquisa Agropecuária Brasileira, 52, 1223-1230.

https://doi.org/10.1590/s0100-204x2017001200011

Baba, S.A., Malik, S.A. (2014). Evaluation of antioxidant and antibacterial activity of methanolic extracts of Gentiana kurroo royle. Saudi Journal of Biological Sciences, 21, 493498.

https://doi.org/10.1016/j.sjbs.2014.06.004 
Brand-Williams, W., Cuvelier, M.E., Berset, C. (1995). Use of a free radical method to evaluate antioxidant activity. LWT-Food Science and Technology, 25, 25-30.

https://doi.org/10.1016/S0023-6438(95)80008-5

Basile, A., Vuotto, M.L., Violante, U., Sorbo, S., Martone, G., Castaldo-Cobianchi, R. (1997). Antibacterial activity in Actinidia chinensis, Feijoa sellowiana and Aberia caffra. International Journal of Antimicrobial Agents, 8(3), 199-203. https://doi.org/10.1016/S0924-8579(97)00376-2

Beyhan, Ö., Elmastaş, M., Gedikli, F. (2010). Total phenolic compounds and antioxidant capacity of leaf, dry fruit and fresh fruit of feijoa (Acca sellowiana, Myrtaceae). Journal of Medicinal Plants Research, 4, 1065-1072.

https://doi.org/10.5897/JMPR10.008

Bontempo, P., Mita, L., Miceli, M., Doto, A., Nebbioso, A., De Bellis, F., Conte, M., Minichiello, A., Manzo, F., Carafa, V., Basile, A., Rigano, D., Sorbo, S., Castaldo Cobianchi, R., Schiavone, E.M., Ferrara, F., De Simone, M., Vietri, M., Cioffi, M., Sica, V., Bresciani, F., de Lera, A.R., Altucci, L., Molinari, A. M. (2007). Feijoa sellowiana derived natural flavone exerts anti-cancer action displaying HDAC inhibitory activities. International Journal of Biochemistry and Cell Biology, 39(10), 1902-1914.

https://doi.org/10.1016/j.biocel.2007.05.010

Cai, Y.Z., Sun, M., Xing, J., Luo, Q., Corke, H. (2006). Structure-radical scavenging activity relationships of phenolic compounds from traditional Chinese medicinal plants. Life Sciences, 78, 2872-2888.

https://doi.org/10.1016/j.lfs.2005.11.004

Cecilia, S.A., Dennise, O., Mercedes, R., Fernanda, Z. (2016). Postharvest quality evaluation of feijoa fruits (Acca sellowiana (Berg) Burret). Agrociencia Uruguay, 20, 14-21.

Chew, A.L., Jessica, J.J.A., Sasidharan, S. (2012). Antioxidant and antibacterial activity of different parts of Leucas aspera. Asian Pacific Journal of Tropical Biomedicine, 2(3), 176-180.

https://doi.org/10.1016/S2221-1691(12)60037-9

Elfarnini, M., Abdel-hamid, A.A., Achir, M., Jamaleddine, J., Blaghen, M. (2018). Antibacterial and antifungal activities of hexane and acetone extracts of sheets and fruits of Feijoa sellowiana O. GSC Biological and Pharmaceutical Sciences, 3, 35-44.

https://doi.org/10.30574/gscbps.2018.3.1.0024
FAO (2015). Food and Agriculture Organization of the United Nations. Global initiative on food loss and waste reduction. Rome, Italy. http://www.fao.org/3/a-i4068e.pdf (accessed May 15, 2020).

Karsli, B., Caglak, E., Li, D., Rubio, N.K., Janes, M., Prinyawiwatkul, W. (2019) Inhibition of selected pathogens inoculated on the surface of catfish fillets by high molecular weight chitosan coating. International Journal of Food Science and Technology, 54, 25-33.

https://doi.org/10.1111/ijfs.13897

Lapcik, O., Klejdus, B., Kokoska, L., Davidova, M., Afandi, K., Kuban, V., Hampl, R. (2005). Identification of isoflavones in Acca sellowiana and two Psidium species (Myrtaceae). Biochemical Systematics and Ecology, 33(10), 983-992.

https://doi.org/10.1016/j.bse.2005.03.007

Mosbah, H., Louati, H., Boujbiha, M.A., Chahdoura, H., Snoussi, M., Flamini, G., Ascrizzi, R., Bouslema, A., Achour, L., Selmi, B. (2018). Phytochemical characterization, antioxidant, antimicrobial and pharmacological activities of Feijoa sellowiana leaves growing in Tunisia. Industrial Crops and Products, 112, 521-531.

https://doi.org/10.1016/j.indcrop.2017.12.051

Mosbah, H., Chahdoura, H., Adouni, K., Kamoun, J., Boujbiha, M.A., Gonzalez-Paramas, A.M., Santos-Buelga, C., Ciudad-Mulero, M., Morales, P., Fernández-Ruiz, V., Achour, L., Selmi, B. (2019). Nutritional properties, identification of phenolic compounds, and enzyme inhibitory activities of Feijoa sellowiana leaves. Journal of Food Biochemistry, 43, e13012.

https://doi.org/10.1111/jfbc.13012

Neilsen, P.V., Rios, R. (2000). Inhibition of fungal growth on bread by volatile components from spices and herbs, and the possible application in active packaging, with special emphasis on mustard essential oil. International Journal of Food Microbiology, 60, 219-229. https://doi.org/10.1016/S0168$\underline{1605(00) 00343-3}$

Pasquariello, M.S., Mastrobuoni, F., Di Patre, D., Zampella, L., Capuano, L.R., Scortichini, M., Petriccione, M. (2015). Agronomic, nutraceutical and molecular variability of feijoa (Acca sellowiana (O. Berg) Burret) germplasm. Scientia Horticulturae, 191, 1-9. https://doi.org/10.1016/j.scienta.2015.04.036 
Peng, Y., Bishop, K.S., Quek, S.Y. (2019). Extraction optimization, antioxidant capacity and phenolic profiling of extracts from flesh, peel and whole fruit of New Zealand grown feijoa cultivars. Antioxidants, 8(5), 141.

https://doi.org/10.3390/antiox8050141

Phan, A.D.T., Chaliha, M., Sultanbawa, Y., Netzel, M.E. (2019). Nutritional characteristics and antimicrobial activity of Australian grown feijoa (Acca sellowiana). Foods, 8, 376. https://doi.org/10.3390/foods8090376

Poodi, Y., Bimakr, M., Ganjloo, A., Zarringhalami, S. (2018). Intensification of bioactive compounds extraction from Feijoa (Feijoa sellowiana Berg.) leaves using ultrasonic waves. Food Bioproducts Processing, 108, 37-50.

https://doi.org/10.1016/j.fbp.2017.12.004

Rossi, A., Rigano, D., Pergola, C., Formisano, C., Basile, A., Bramanti, P., Senatore, F., Sautebin, L. (2007). Inhibition of inducible nitric oxide synthase expression by an acetonic extract from Feijoa sellowiana Berg. fruits. Journal of Agricultural and Food Chemistry, 55, 5053-5061.

https://doi.org/10.1021/jf070510d

Safari, M., Ahmady-Asbchin, S. (2019). Evaluation of antioxidant and antibacterial activities of methanolic extract of medlar (Mespilus germanica L.) leaves. Biotechnology and Biotechnological Equipment, 33, 372-378.

https://doi.org/10.1080/13102818.2019.1577701

Santos, P.H., Ribeiro, D.H.B., Micke, G.A., Vitali, L., Hense, H. (2019). Extraction of bioactive compounds from feijoa (Acca sellowiana (O. Berg) Burret) peel by low and high-pressure techniques. The Journal of Supercritical Fluids. 145, 219-227.

https://doi.org/10.1016/j.supflu.2018.12.016

Scalbert, A. (1991). Antimicrobial properties of tannins. Phytochemistry, 30, 3875-3883.

https://doi.org/10.1016/0031-9422(91)83426-L

Singleton, V.L., Rossi, J.A. (1965). Colorimetry of total phenolics with phosphomolybdic-phosphotungstic acid reagents. American Journal of Enology and Viticulture, 16, 144-158.

Souza, A.G., Amarante, C.V.T., Steffens, C.A., Beninca, T.D.T., Padilha, M. (2016). Postharvest quality of feijoa flowers treated with different preservative solutions and 1methylcyclopropene. Revista Brasileira de Fruticultura, 38, e-759.

https://doi.org/10.1590/0100-29452016759
Sun-Waterhouse, D. (2011). The development of fruit-based functional foods targeting the health and wellness market: a review. International Journal of Food Science and Technology, 46, 899-920.

https://doi.org/10.1111/j.1365-2621.2010.02499.x

Tanko, H., Carrier, D.J., Duan, L., Clausen, E. (2005). Pre- and post-harvest processing of medicinal plants. Plant Genetic Resources, 3, 304-313.

https://doi.org/10.1079/PGR200569

Tuncel, N.B., Yllmaz, N. (2015). Optimizing the extraction of phenolics and antioxidants from feijoa (Feijoa sellowiana, Myrtaceae). Journal of Food Science and Technology, 52, 141-150.

https://doi.org/10.1007/s13197-013-0968-0

Turkmen, N., Sari, F., Velioglu, S. (2006). Effects of extraction solvents on concentration and antioxidant activity of black and black mate tea polyphenols determined by ferrous tartrate and Folin-Ciocalteau methods. Food Chemistry, 99, 835-841.

https://doi.org/10.1016/j.foodchem.2005.08.034

Viganó, J., Machado A.P.F., Martínez, J. (2015). Sub- and supercritical fluid technology applied to food waste processing. The Journal of Supercritical Fluids, 96, 272-286.

https://doi.org/10.1016/j.supflu.2014.09.026

Vuotto, M.L., Basile, A., Moscatiello, V., De Sole, P., Castaldo-Cobianchi, R., Laghi, E., Ielpo, M.T.L. (2000). Antimicrobial and antioxidant activities of Feijoa sellowiana fruit. International Journal of Antimicrobial Agents, 13(3), 197-201.

https://doi.org/10.1016/S0924-8579(99)00122-3

Weston, R.J. (2010). Bioactive products from fruit of the feijoa (Feijoa sellowiana, Myrtaceae): a review. Food Chemistry, 121, 923-926.

https://doi.org/10.1016/j.foodchem.2010.01.047

Yakoub, A.R.B., Abdehedi, O., Jridi, M., Elfalleh, W., Nasri, M., Ferchichi, A. (2018). Flavonoids, phenols, antioxidant, and antimicrobial activities in various extracts from Tossa jute leave (Corchorus olitorus L.). Industrial Crops and Products, 118, 206-213.

https://doi.org/10.1016/j.indcrop.2018.03.047

Zhu, F. (2018). Chemical and biological properties of feijoa (Acca sellowiana). Trends in Food Science and Technology, 81, 121-131. https://doi.org/10.1016/j.tifs.2018.09.008 